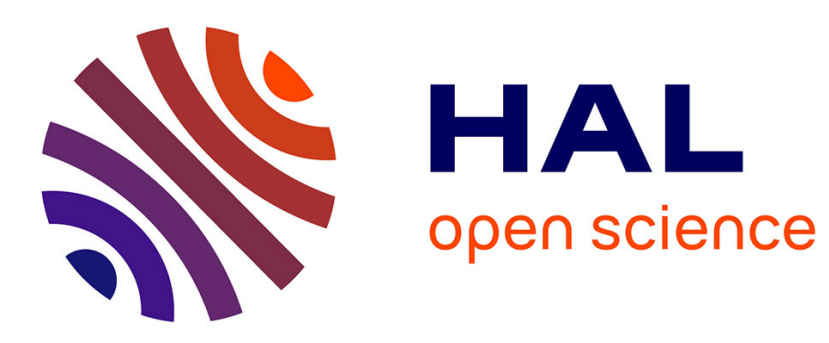

\title{
Visual structure of landscapes seen from built environment
}

Mohamed Hilal, Daniel Joly, Damien Roy, Gilles Vuidel

\section{To cite this version:}

Mohamed Hilal, Daniel Joly, Damien Roy, Gilles Vuidel. Visual structure of landscapes seen from built environment. Urban Forestry and Urban Greening, 2018, 32, pp.71-80. 10.1016/j.ufug.2018.03.020 . hal-01774883

\section{HAL Id: hal-01774883 \\ https://hal.science/hal-01774883}

Submitted on 30 Apr 2018

HAL is a multi-disciplinary open access archive for the deposit and dissemination of scientific research documents, whether they are published or not. The documents may come from teaching and research institutions in France or abroad, or from public or private research centers.
L'archive ouverte pluridisciplinaire HAL, est destinée au dépôt et à la diffusion de documents scientifiques de niveau recherche, publiés ou non, émanant des établissements d'enseignement et de recherche français ou étrangers, des laboratoires publics ou privés. 
Urban Forestry \& Urban Greening 32 (2018) 71-80

\title{
Visual structure of landscapes seen from built environment
}

\author{
M. Hilal ${ }^{\mathrm{a},{ }^{*}, 1}$, D. Joly ${ }^{\mathrm{b}, 1}$, D. Roy ${ }^{\mathrm{b}}, \mathrm{G}$. Vuidel ${ }^{\mathrm{b}}$ \\ ${ }^{a}$ CESAER, AgroSup Dijon, INRA, Université Bourgogne Franche-Comté, F-21000 Dijon, France \\ ${ }^{b}$ Laboratoire ThéMA, UMR6049 CNRS et Université Bourgogne Franche-Comté, F-25030 Besançon, France
}

\begin{abstract}
Vegetation in cities keeps climate warming down and improves the health of people and ecosystems while making for a pleasant urban setting. Contemporary urban planning promotes sustainable green cities. Green and blue infrastructures, which help maintain an eco-friendly environment, are the primary instruments of this movement. This paper attempts to show the relative weight of plant life (trees, grass, orchards, etc.) seen from buildings in different urban settings (local urban patterns of high or low density of buildings). Landscapes open to view are identified by combining a digital elevation model and an 11-class land-use layer (including buildings, facilities, grey infrastructures, green and blue surfaces) in a computational tool that calculates viewsheds. The results show that vegetation is very much present in urban landscapes. In high-density built areas of city centres, the landscape is varied although not open and is dominated by trees, low-rise residential buildings and grass. Grey infrastructures and bushes are also very common. In low-density built areas the rank order of objects in view is similar but the landscape is more panoramic.
\end{abstract}

Keywords: built environment; landscape viewshed; land use; digital elevation model; topographic map

\section{Introduction}

Human settlements from the major metropolises to the tiniest hamlets are characterized by land use that is composed of buildings and grey (roads, parking spaces, airports, etc.), blue (water bodies, rivers, canals, etc.) and green (urban parkland, gardens, woodland, etc.) infrastructures (Alavipanah et al., 2017). The spatial patterns and the respective dimensions of these forms of land use, especially the presence of water and plant life, affect the well-being of residents and the functioning of ecosystems (Ahern, 2007; Alberti and Marzluff, 2004; Andersson and Colding, 2014; Conedera et al., 2015; Ervin et al., 2012; Tannier et al., 2016). Today half of the world's population and four out of five Europeans live in cities. The resulting urbanization is transforming land use and modifying landscapes. Areas for residential use, economic activities and infrastructures sprawl out into the surrounding countryside and more remote rural areas. The ensuing loss of agricultural and natural land is detrimental to

\footnotetext{
${ }^{*}$ Corresponding author.

E-mail addresses: mohamed.hilal@inra.fr (M. Hilal), daniel.joly@univ-fcomte.fr (D. Joly), damien.roy@univfcomte.fr (D. Roy), gilles.vuidel@univ-fcomte.fr

${ }^{1}$ These authors contributed equally.
} 
biodiversity and reduces residential satisfaction associated with landscape. The spread of cities, experienced in most developed countries, can be explained in part by the search for lower property prices than in town and by better transport links. Households can commute quickly to employment areas and commercial, cultural and educational infrastructures and businesses enjoy good market access (Hilal et al., 2017). These two factors are compounded by the search for landscapes with a "green" setting and vast open spaces. "Open space is often cited as a primary attractor of urban and suburban residents to exurban areas located just beyond the metropolitan fringe" (Irwin and Bockstael, 2001). Le Jeannic (1997) speaks of the hankering in France to live "in a natural setting far from the bustle of cities, in spacious houses with gardens while holding on to the source of remuneration of a job in town". Landscapes with plentiful "green" and "open spaces" are associated with neighbourhood satisfaction (Ellis, Lee \& Kweon, 2006; Gruber \& Shelton, 1987; Hur \& MorrowJones, 2008; Hur, Nasar \& Chun, 2010; Kearney, 2006; Lamb \& Purcell, 1990; Lee, Ellis, Kweon, \& Hong, 2008) and higher property values (Joly et al., 2009; Wen et al., 2015). They promote viable ecosystems and human health in urban areas (Tzoulas et al., 2007; Velarde et al., 2007) and play a part in adapting cities for climate change.

Household residential choice thus results generally from a decision based on having ready access both to resources generally associated with the urban fabric (work, shops, etc.) and more specifically to rural environmental and landscape amenities. Yet many people continue to live in cities and it is worth analysing the landscape components they see daily. Urban landscapes have long been thought of in terms of architectural and city planning projects designed to maintain or introduce "nature" into cities. More recently, the management of environmental amenities has been integrated into the issues and policies surrounding sustainable development (Clay and Daniel, 2000; Davodeau, 2005; Shechter et al., 1981). It is becoming one of the major concerns of public and private sector actors in all areas from the largest agglomerations to the smallest localities. From this perspective, landscape properties form the basis for analysis ahead of an evaluation of the potential and services provided by environmental amenities.

This paper addresses two questions. Firstly, how green is the landscape in urban setting and, secondly, how building density affects the viewshed? In section 2, we propose to refine the measurement of aesthetic services provided by green spaces. This measurement is based on visual landscape analysis at a fine spatial resolution $(5 \mathrm{~m})$ over a large area $(126 \times 110 \mathrm{~km})$. We use an original land-use layer that includes buildings, facilities, grey infrastructures, and green and blue surfaces. To calculate viewsheds, this layer is coupled with a digital elevation model (section 3 ). We then produce various statistical indicators of landscape structure (presence and weight of open green spaces and wooded areas, built areas, etc.). These indicators are used to compare the visibility of "green" infrastructures in two 
different urban building patterns with high and low building densities (section 4). The contribution of the results and the method's limits are discussed in section 5.

\section{Methodological background}

\subsection{Monitoring green spaces}

Urban green spaces support a lot of ecosystem services, beyond the simple provisioning service that remains their primary function (Bolund and Hunhammar, 1999; Gómez-Baggethun and Barton, 2013). Following Chan et al. (2012), "ecosystem service approaches have become a prominent basis for planning and management". "Nature" in urban settings consists of a stock of parks and gardens, trees planted along streets, squares and flower beds, green corridors and green spaces, and also pets, insects, birds, and other wildlife. Given the diversity of green spaces and services potentially provided, it is important to identify the correlations, both positive or negative, between different levels of service provision. The question of the compatibility between aesthetic and ecological values of the landscape has been examined from different disciplinary angles. While some studies show that the most ecologically rich landscapes are not the most visually valued (Hands and Brown, 2002; Williams and Cary, 2002), others indicate that people like ecologically valued landscapes (Klein, 2013; Tyrväinen et al., 2003). Certain contextual factors, such as the type of landscape studied or the location of the study, strongly affect the conclusions of these studies (Gobster et al., 2007; Matsuoka and Kaplan, 2008).

These contrasting results show that ecosystem services are not necessarily perceived directly by people. However, the results of cost-benefit analysis based on ecosystem services and management suggest that the quality of green spaces should be considered in policy making (Chang et al., 2017). In addition, the preservation and the development of green infrastructure in cities is one of the conditions for creating or maintaining sustainable cities, especially in compact cities (Artmann et al., 2017b; Wolch et al., 2014).

In this paper, we propose to refine the measurement of aesthetic services provided by green spaces. This measurement is based on visual landscape analysis and can be useful for urban and regional research and planning applications. Indeed, we propose a method for evaluating the visual character of the landscape that has several advantages. Our method uses easily accessible data and is consistent over wide open spaces. It provides objective and transparent indicators of landscape structure and it is easily integrated with information about other landscape functions.

\subsection{Visual landscape analysis}

Visual landscape analysis studies have, to a very large extent, used landscape photographs as substitutes for landscape to assess aesthetic qualities and preferences. Many methods have been proposed in many disciplinary fields. However, the capacity of photographs to adequately represent 
the multidimensional nature of real landscapes has been questioned and criticized (Palmer, 2000; Tveit et al., 2006). Recent works use emerging web-based tools such as Google Street View to calculate a green view index (Li et al., 2015), or Geo-Tagged Photographs from Social Media Data like Panoramio and Flickr (Figueroa-Alfaro and Tang, 2017) to evaluate aesthetic value.

The use of geographic information systems (GIS) for the visual analysis of landscape is an alternative approach to the use of photographs. GIS-based methods and techniques have been available for many years, but their use was limited by data acquisition problems and the complexity of processing (Nijhuis et al., 2011). Today, there are large amounts of data available and numerous GIS software packages that can be used to deal with visibility modelling: commercial software (ArcGIS, MapInfo Vertical Mapper, Geoconcept 3D, ENVI or ERDAS) and free GIS software (OpenJump, Saga GIS, QGIS and GRASS). However, these packages offer limited functions for computing viewsheds and require many other operations to conduct complete visibility analyses. The use of these tools to measure ecosystem services or quantify green infrastructure is still relatively limited (Klouček et al., 2015; Loures et al., 2015).

In this paper we use PixScape (Sahraoui et al., 2016a, 2016b), a software package that integrates a large set of functions for modelling landscape visibility and for computing composition and configuration of the visual content.

As input, we use existing cartographic data to produce an ultra-fine resolution $(5 \mathrm{~m})$ land-use map. This layer is well suited for the visual analysis of the landscape of heterogeneous built spaces mixing impermeable features like buildings (residential, commercial, industrial), grey infrastructure (roads and artificially surfaced areas) with green and blue objects (parks, gardens, agricultural crops, meadows, forests, vineyards, rivers and water bodies). This information is produced at low cost, without using satellite and/or LIDAR imagery. The land-cover layer also has the advantage of generating fewer ambiguities in the identification of its components. Finally, our approach is systematic (all points of space are analysed) and allows us to cover a large area $\left(8800 \mathrm{~km}^{2}\right)$ with varied urban forms ranging from cities to small villages. This analysis is used for calculating aggregated statistical indicators that are understandable and easy-to-use for policy-makers and urban and land planners.

\subsection{Identification of local built-up patterns}

Building density information is fundamentally important for urban design, planning and management and for urban environmental studies (Yu et al., 2010). The relationship between built and non-built space is essential when analysing urban morphology. Local built patterns can be solid or compact (with little or no space between buildings), dispersed (when buildings are far apart and not 
connected), or even isolated (with no other buildings in the neighbourhood). We use an innovative method (Caruso et al., 2017; Wu et al., 2017) combining graph theory and local spatial autocorrelation analysis to automatically identify such local built patterns (MST and LISA methodology). The input of the method is the precise geographic location of all individual buildings. The method then consists in constructing a graph linking each building to its neighbours, subdividing the graph into subgraphs, and then further subdividing these into different built patterns identified in a statistically robust manner from a local index of spatial association (LISA) (Anselin, 1995). The built patterns differentiate heterogeneous settlements from homogeneous clusters of either high-density built areas (connected buildings or buildings with little space between them) or low-density built areas (not connected and further apart).

\section{Material and method}

\subsection{Study area}

The Côte-d'Or is in the centre-east of France (Fig. 1). It has 527400 inhabitants (2012) and covers an area of about $8800 \mathrm{~km}^{2}$. It fits into a rectangle with sides of $126 \times 110 \mathrm{~km}$. Topography and landuse fall into four main "geographical" units. The northern half comprises plateaux covered by forest and large cereal farms. In the southern half, several agricultural zones run from west to east: landscapes of meadowland and hedgerows and of forests in the west; valleys with diversified farming (fruit, cereals, livestock) in the centre; and the floodplain of the River Saône to the east, where forests stand beside intensively-farmed arable land (market gardening and field crops). These last two areas are separated by an escarpment along which runs a narrow strip of vineyards (la Côte d'Or) that gives Burgundy its reputation for fine wines. 


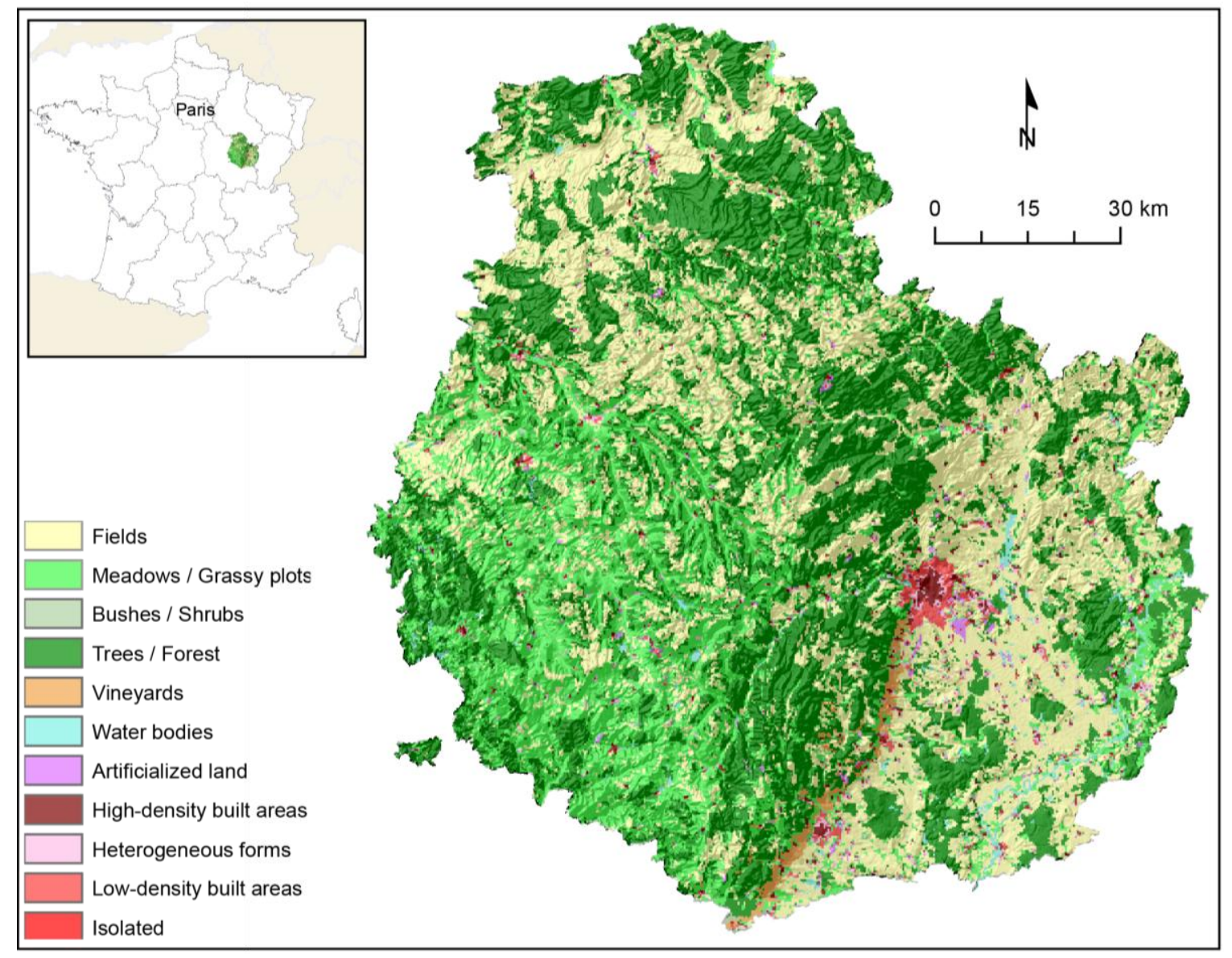

Fig. 1. Study area (bounding coordinates - Lambert93, RGF 93: N 6771336, W 780330, E 890290, S 6645776)

Both elevation and land-use are required to calculate the viewshed and identify the landscape structure. This $5 \mathrm{~m}$ resolution raster information is produced from a combination of multi-source data: a $50 \mathrm{~m}$ digital elevation model $\left(\mathrm{IGN}^{2}\right)$; the French national topographic database (IGN); the Land Parcel Identification System (LPIS) database (ASP ${ }^{3}$ and IACS,EU ${ }^{4}$ ); and Corine Land Cover (EEA-JRC, $\left.\mathrm{EU}^{5}\right)$.

\subsection{Construction of a land-use/land-cover model}

The information layer on land-use/land-cover (LULC) is obtained by merging multiple sources (Hilal et al., 2016; Smith et al., 2007; Thiemann et al., 2010; Wyatt, 2004). The topographic database contains a land cover description employed for topographic map production at a scale of 1:25 000, with a minimum unit of collection of approximately 8 hectares. The information is relatively precise on the contours of urban areas (buildings), road and rail infrastructures, hydrography, and trees and shrubs;

\footnotetext{
2 Institut Géographique National, the French national geographic institute.

${ }^{3}$ Agency for Services and Payment, French public institution responsible for the implementation of national and European public policies.

${ }^{4}$ Integrated Administration and Control System, European Union.

${ }^{5}$ European Environment Agency, Joint Research Center, European Union.
} 
however, it does not make it possible to distinguish the land uses within the agricultural, forested, or natural areas. The LPIS database, which draws on the digital cadastral database (1:500-1:5000), allows us to identify those agricultural areas for which subsidies are sought under the European Common Agricultural Policy (CAP). It was used to determine the agricultural land-use (grass-like vegetation and arable land) on the scale of cadastral parcels. Corine Land Cover (CLC) is thematically much richer, in particular in agricultural areas, but its spatial resolution, which is rather coarse (approximately 1:100 000), means it cannot identify the nature of a polygon of less than 25 hectares. Despite its rather coarse resolution, CLC has a thematically richer land-use nomenclature than can be used to refine plant cover.

The land-cover information layer was constructed in two steps. The first was to generate a simplified geometry of land use in vector form (polygons and lines). The operation begins by detecting the "polygonal skeleton" that integrates roads, railways, and the hydrographic network attributing to them a footprint proportional to their width. Next are added (1) agricultural surface features from the LPIS (field, meadow, orchard, other agriculture use); (2) plant-covered areas, mostly forest and orchard; and (3) artificialized surfaces (buildings, quarries, parking areas, etc.). Each addition is made by masking and expansion so as to approximate the "polygonal skeleton". The features not described in the topographic database and the LPIS are categorized as "unidentified polygons". Some of this class is marked down as grassland-lawn using CLC classes "321" (Natural grasslands) and "231" (Pastures). Processing is done with the PostGIS functionalities: intersection, union, dilation, erosion, etc. of polygons or lines (PostGIS, 2018).

This stage enables eight land-use categories to be defined: (1) urban footprints, (2) fields, (3) meadows, (4) forests, (5) orchards, (6) rivers and water bodies, (7) road and rail infrastructure footprints, (8) unidentified polygons.

This first vectorial geometric model is changed into a $5 \mathrm{~m}$ resolution raster layer and then supplemented to produce a land-use layer compatible with the landscape analysis contemplated. Categories (4), (6) and (7) describing relatively homogeneous and straightforward landscape features were kept unchanged. The improvement described below was primarily for heterogeneous and complex landscape features (categories (1), (2), (3) and (5)) that are replaced by simple landscape objects (buildings, mineral surfaces, copses, fields, grass-covered areas, etc.). The improvement also covers pixels in category (8).

Pixels of the urban footprint (1) are differentiated into three types of landscape items: the built area, parking areas, and urban plant cover. The built area is incrusted by distinguishing its height and function: (11, LRM) Low-rise Residential or Mixed buildings ( $<12$ metres 1-2 storeys); (12, HRM) 
High-rise Residential or Mixed buildings ( $\geq 12$ metres $~ 3$ storeys and more); (13, ICF) Industrial or Commercial buildings and other Facilities; (14) agricultural buildings. Parking areas were also created around some buildings and classified as category (7): a $5 \mathrm{~m}$ (1 pixel) buffer around HRM polygons and ICF polygons between 50 and $999 \mathrm{~m}^{2}$; a $25 \mathrm{~m}$ buffer for ICF polygons of $1000 \mathrm{~m}^{2}$ (5 pixels) and more. The buffer sizes were established from existing planning and building codes. Non-built and non-parking areas in the urban footprint are converted into plant cover in the following proportions: grass $50 \%$ of pixels; trees $25 \%$; shrubs and bushes $25 \%$. These proportions are based on the visual identification and quantification of green areas/expanses in built the environment using orthophoto images. This is done by first converting non-built and non-parking areas into grass pixels and then drawing tree pixels and shrub and bush pixels at random.

For the field (2) and meadow (3) categories identified with tree cover (presence of trees in CLC), $10 \%$ of randomly drawn pixels are converted into trees. The pixels classified as orchards (5) and that are within a polygon classified as vineyard (221) in CLC are reclassified as vineyard. The remaining pixels are first converted into grass and then into shrubs and bushes by randomly drawing $70 \%$ of the pixels.

Pixels in category (8), "unidentified polygons", are reclassified by comparison with the CLC polygons (annex 1).

\subsection{Construction of the $5 \mathrm{~m}$-resolution digital elevation model}




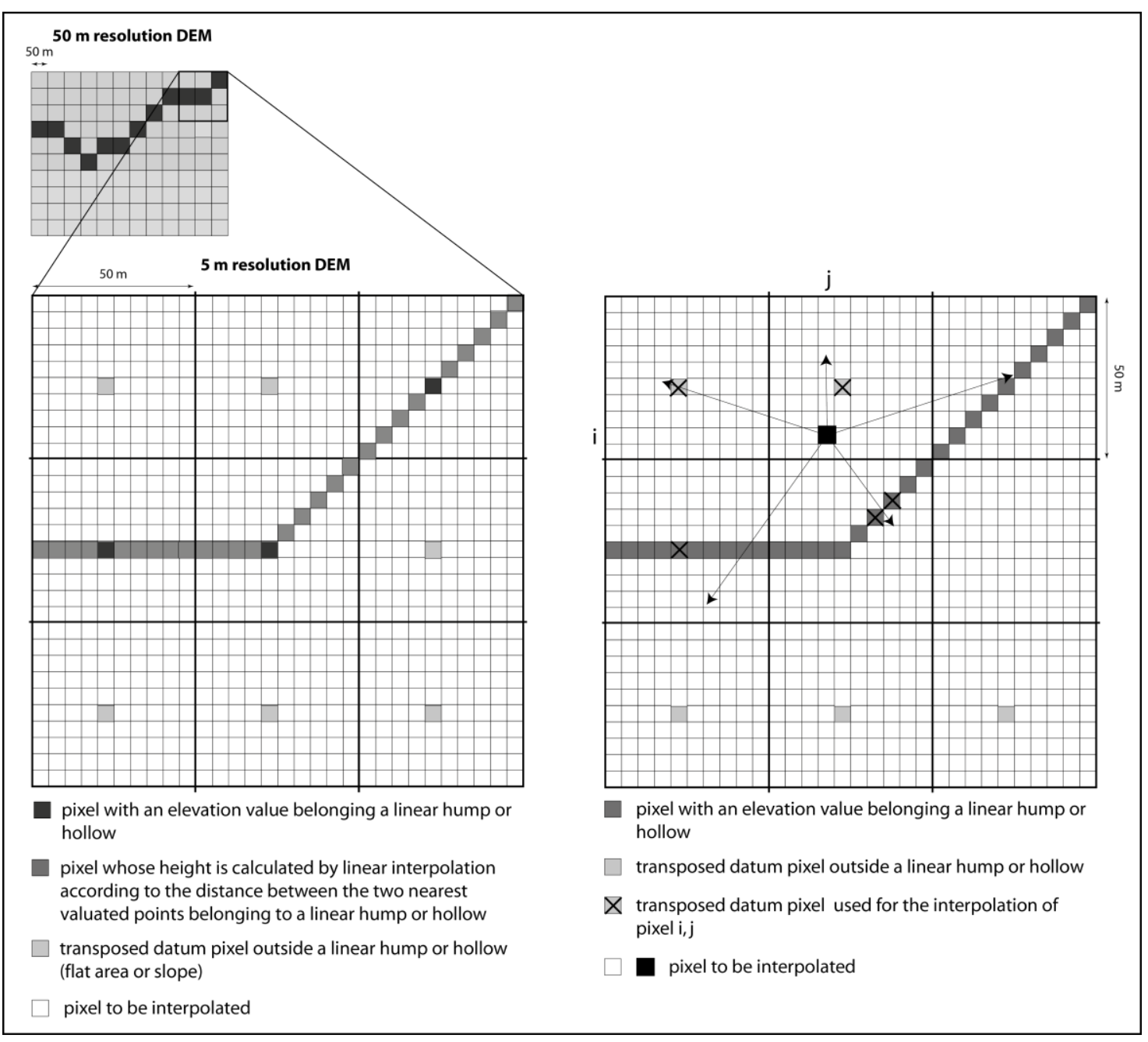

Fig. 2. Spatial downscaling from a $50 \mathrm{~m}$ DEM resolution grid to a $5 \mathrm{~m}$ DEM resolution grid evaluated

We use the $50 \mathrm{~m}$ digital elevation model (DEM) database produced by IGN to generate à $5 \mathrm{~m}$ DEM. Many studies propose algorithms to recover significant landforms or the "skeleton" from a DEM and then use them to generate a coarser resolution DEM (Ai and Li, 2010; Zakšek and Podobnikar, 2005; Zhou and Chen, 2011). Based on a similar idea, we have developed an algorithm that uses the significant features of the terrain to reconstruct a finer DEM (Joly, Bois, \& Zaksek, 2012). The 50m DEM was expanded 100 fold to generate a matrix of points of $5-\mathrm{m}$ resolution. The elevation of each pixel of the 50m DEM was transposed unchanged onto one of the pixels close to the centre of the 10*10 pixel 5-m window resulting from the expansion (Fig. 2). To avoid exaggerating the softening of the relief, allowance was made for relief skeleton lines (ridges, thalwegs) that were identified first on the $50 \mathrm{~m} \mathrm{DEM}$ and then marked and linearized on the $5 \mathrm{~m}$ matrix. The altitude values of pixels close to the centre of the $10 * 10$ window belonging to skeleton lines were used for linear interpolation (IDW) of the intermediate pixels. 
The matrix generated has pixels of known elevation values (central pixels or pixels on the skeleton line) and unevaluated pixels (blank in figure 2) that are subject to IDW interpolation with an adaptation as to the choice of neighbours (the five nearest neighbours to the point to be interpolated are selected in the five $72^{\circ}$ angular sectors surrounding it).

This DEM layer is accompanied by a digital surface model (DSM) where the height of geographical objects (LULC) dispersed over the ground surface are recorded. The height of buildings is found from the topographic database. The height of other features is standard: zero for fields, meadowland, artificial surfaces and water, $1 \mathrm{~m}$ for vineyards, $4 \mathrm{~m}$ for shrubs and $20 \mathrm{~m}$ for trees.

\subsection{Viewshed modelling}

Three layers of raster data are used as input to compute the viewshed: LULC, DEM and DSM described previously (grids of $21992 \times 25112$ pixels at 5 m resolution; 2.06 GB non compressed TIFF). The viewshed is modelled by the method described by Joly et al. (2009). It is calculated by the divergent rays method simulating the view of a virtual observer in all directions (De Floriani \& Magillo, 1999; De Floriani, Marzano \& Puppo, 1994). The height of the observer is set to $1.7 \mathrm{~m}$ from the ground. The viewshed is calculated from each pixel of the LULC grid. This processing is done using the open source PixScape software (Sahraoui et al., 2016a, 2016b) at the Franche-Comté University mesocentre computing facility.

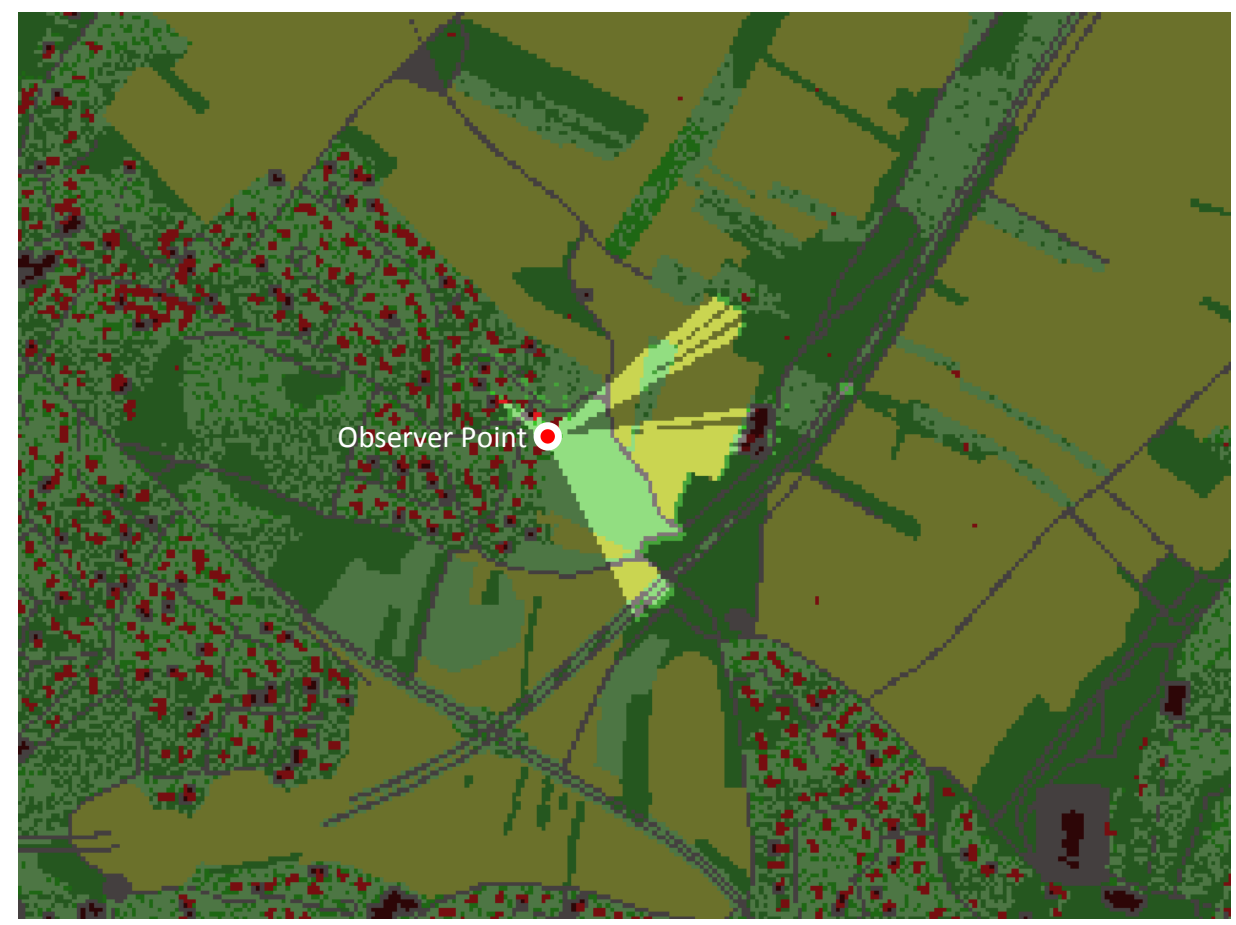

Fig. 3. Example of viewshed output for one observing point (dark colors=not visible / light colors = visible) 
Processing yields 11 result matrices, one for each land-use layer class, storing the areal values seen from each point. For example, the "cropland" matrix indicates the area of cropland in the viewshed by scanning the horizon. This value will be 0 if no fields can be seen; otherwise it will be minimal $\left(25 \mathrm{~m}^{2}\right)$ if a single pixel of the $5 \mathrm{~m}$ resolution base is visible and much higher if a large amount of cropland is in sight.

Because of (1) the lengthy computing time and the size of the results matrices (same size as the input) and (2) the fact that landscape seen from adjacent buildings is similar, the landscape analysis is performed for 10000 pixels drawn at random from each of the two forms of built area. These 10000 points represent $1.3 \%$ of pixels for "high-density built areas" and $2 \%$ of pixels for "low-density built areas".

\section{Results}

\subsection{Description of land use and built area}

Table 1 records the surface area and percentage per land use/cover classes. The Côte-d'Or covers 878776 hectares. It is predominantly forest and wooded areas, which occupy 341307 hectares, that is, $39 \%$ of the territory. Cropland and meadows and grass cover $56 \%$ of the area, artificialized land and buildings cover 3.5\% and bushes/shrubs, (vineyards) and water bodies each account for less than $1 \%$.

Table 1. Surface area and percentage per land use/cover classes

Artificialized land: roads, railways, footpaths, parking areas, etc.

\begin{tabular}{|l|c|c|c|}
\hline \multicolumn{1}{|c|}{ Land use/cover } & \# pixels & hectares & $\%$ \\
\hline Buildings & 1996867 & 4992 & 0.57 \\
\hline Fields & 121126338 & 302816 & 34.46 \\
\hline Meadows / Grassy plots & 75620838 & 189052 & 21.51 \\
\hline Bushes / Shrubs & 1439095 & 3598 & 0.41 \\
\hline Trees / Forest & 136522957 & 341307 & 38.84 \\
\hline Vineyards & 2201146 & 5503 & 0.63 \\
\hline Water bodies & 2257082 & 5643 & 0.64 \\
\hline Artificialized land & 10346182 & 25865 & 2.94 \\
\hline Total & 351510505 & 878776 & 100.00 \\
\hline
\end{tabular}

The characteristics of the urban form categories obtained via MST and LISA methodology (Caruso et al., 2017) are shown in table 2. Most buildings are in homogeneous urban compartments with distinctive morphological forms. The first, accounting for nearly half the buildings (47\%), is for sectors where buildings are adjoining or very closely spaced (median distance of $7 \mathrm{~m}$ between centroids). The Building Coverage Ratio (BCR) and Floor Area Ratio (FAR) are very high. The sectors are located in dense 
central urban zones corresponding to old centres of cities and village cores. These sectors generally combine varied uses such as housing, offices, shops and services. The second morphological form accounts for $17 \%$ of buildings. It corresponds to more recent extensions with urban compartments where the regularly patterned constructions are spaced further apart (median distance $19 \mathrm{~m}$ ). The building density indicators are almost halved. These sectors comprise mostly detached housing, sometimes with the shops and services required for social life.

Table 2. Characteristics of local pattern

\begin{tabular}{|c|c|c|c|c|c|c|c|}
\hline \multirow[t]{2}{*}{ Local pattern } & \multicolumn{2}{|c|}{ Number of buildings } & \multicolumn{3}{|c|}{$\begin{array}{l}\text { Inter-building distance } \\
\text { (metres) }\end{array}$} & \multicolumn{2}{|c|}{$\begin{array}{c}\text { Density index } \\
\text { (\%) }\end{array}$} \\
\hline & & & mean & median & st.dev & BCR & FAR \\
\hline High-density built areas & 182083 & $(47 \%)$ & 10 & 7 & 11 & 22.3 & 50.4 \\
\hline Low-density built areas & 67802 & $(17 \%)$ & 23 & 19 & 23 & 11.5 & 27.6 \\
\hline Heterogeneous forms & 137019 & $(35 \%)$ & 19 & 14 & 21 & 7.0 & 14.1 \\
\hline Isolated & 2508 & $(1 \%)$ & // & // & // & 0.2 & 0.4 \\
\hline All & 389412 & $(100 \%)$ & 15 & 11 & 18 & 8.1 & 18.0 \\
\hline
\end{tabular}

The BCR measures the building density in two-dimension space: it is defined as the ratio of the building coverage area (i.e. the area of building footprint) to the size of land lot. The FAR describes the three-dimensional building density: it is defined as the ratio of gross building floor area to the size of land lot. (Yu et al., 2010)

The heterogeneous urban compartments contain $35 \%$ of the buildings. The relevant sectors display no regular pattern. Buildings do not seem to be arranged by uniform rules and are irregularly spaced. These sectors lie between the two types of homogenous compartments and form transition spaces. Isolated buildings (1\%) are scattered constructions more than $200 \mathrm{~m}$ from the nearest construction.
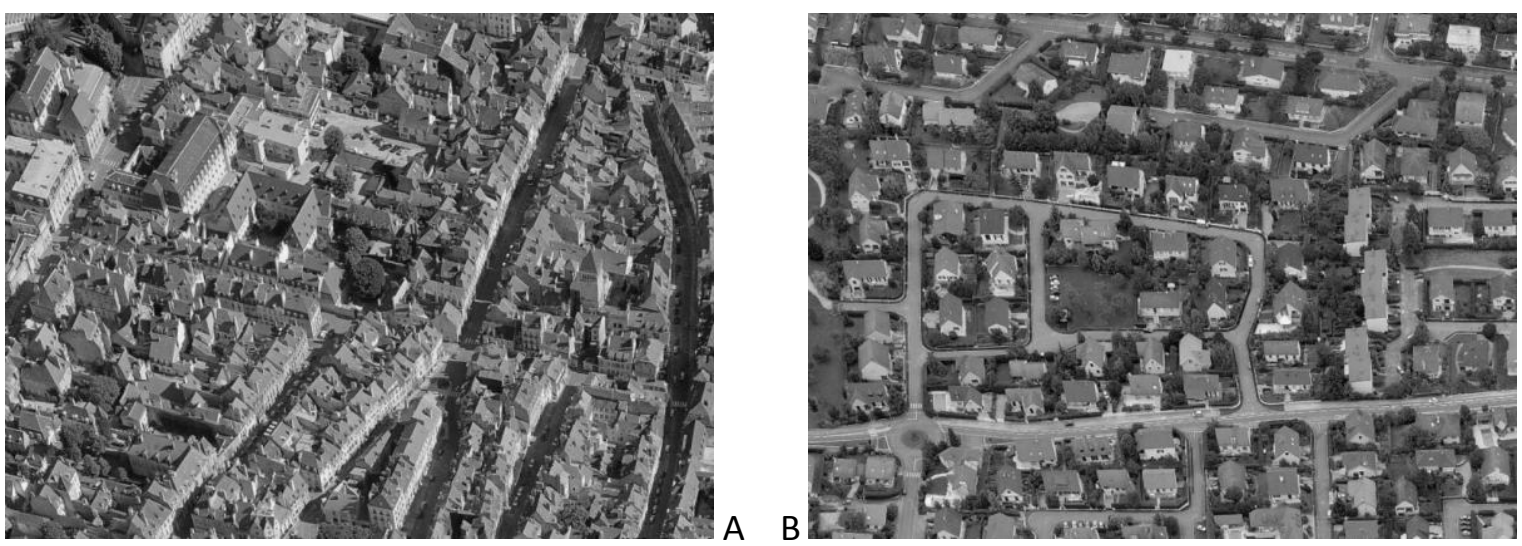

Source: Pictometry bird's eye imagery 2017, Microsoft Bing areal.

Fig. 4. Example of (A) high and (B) low-density built areas 
Table 3. Characteristics of local pattern

\begin{tabular}{|l|c|c|c|}
\hline \multicolumn{1}{|c|}{ Built-up forms } & \# pixels & hectares & \multicolumn{1}{c|}{$\%$} \\
\hline High-density built areas & 759284 & 1898 & 38.0 \\
\hline Low-density built areas & 507681 & 1269 & 25.4 \\
\hline Heterogeneous forms and isolated buildings & 729902 & 1825 & 36.6 \\
\hline Total buildings & 1996867 & 4992 & 100.0 \\
\hline
\end{tabular}

\subsection{Landscapes and built forms}

For the sake of simplicity, we use only the two categories high and low density of buildings here. The frequency with which the 11 objects are seen reflects the quality of the landscape as seen from buildings that are differentiated by which of the two built forms they belong to.

Table 4. Frequency of occurrence of buildings and grey infrastructure objects seen in the viewshed from high and low-density built areas (\%)

\begin{tabular}{|l|c|c|}
\hline \multicolumn{1}{|c|}{ Buildings and grey infrastructure objects } & $\begin{array}{c}\text { High-density } \\
\text { built areas }\end{array}$ & $\begin{array}{c}\text { Low-density } \\
\text { built areas }\end{array}$ \\
\hline Low-rise homes and businesses & 90 & 39 \\
\hline High-rise homes and businesses & 14 & 5 \\
\hline Commercial, industrial, leisure and educational facilities & 55 & 46 \\
\hline Agricultural facilities (buildings, greenhouses) & 5 & 3 \\
\hline Grey infrastructures (footpaths, parking areas, roads, railways, etc.) & 76 & 46 \\
\hline
\end{tabular}

Grey infrastructures, low-rise residential buildings and industrial and commercial buildings are the most frequently seen man-made features (tab. 4). High-rise residential and farm buildings are seldom within view. The frequency with which low-rise residential buildings are in view can double depending on whether the location is in the town centre (high density of buildings: $90 \%$ ) or on the outskirts (low density of buildings: $39 \%)$. The gap is even wider for the high-rise residential which is far more often visible from high-density built areas (14\%) than from low-density built areas (5\%).

Table 5. Frequency of occurrence of green and water objects seen in the viewshed from high and low density-built areas (\%)

\begin{tabular}{|l|c|c|}
\hline \multicolumn{1}{|c|}{ Green and water objects } & $\begin{array}{c}\text { High-density } \\
\text { built areas }\end{array}$ & $\begin{array}{c}\text { Low-density } \\
\text { built areas }\end{array}$ \\
\hline Trees / Woods / Forest & 94 & 55 \\
\hline Bushes / Shrubs & 62 & 37 \\
\hline Vineyards & 1 & 1 \\
\hline Meadows / Grass & 84 & 49 \\
\hline Fields & 10 & 12 \\
\hline Water bodies & 3 & 3 \\
\hline
\end{tabular}


The frequency of occurrence of green and water objects also varies widely depending on the features (tab 5): trees and meadows/grass are very much present in viewsheds whereas fields (10\%), water bodies (3\%) and vineyards (1\%) are seldom within sight. Bushes and shrubs are intermediate. Counterintuitively, trees are present in almost all compact urban landscapes (94\%) but only one time in two in low-density built areas. The same magnitude of decline between high and low-density built areas also holds for bushes/shrubs and meadows/grass.

The most densely built urban form offers a view of landscape dominated by trees, low-rise residential buildings, meadows/grass and grey infrastructures. The landscape of low-density built areas is similar overall, but those four geographical features are less commonly seen; for example, trees are seen in $94 \%$ of compact spaces, but the figure falls to $55 \%$ in the less compact form. Moreover, this drastic decline in the four predominant features seen is not offset by a rise in other features. It may be concluded that town centres offer a more heterogeneous landscape than the outskirts. On average six features are within view from high-density built areas compared with just three from less compact areas.

\subsection{Visual amplitude of the landscape}

The mean area of a feature that is within view is complementary to its frequency of occurrence in the viewshed. It can be easily calculated by just multiplying the number of pixels of the object in question seen by $25 \mathrm{~m}^{2}$ ( $5 \mathrm{~m}$ resolution). The area of low-rise residential buildings in view is low (tab. 6). As a general rule, the area in the field of view covered by man-made objects is low, except for artificialized land (roads, parking areas, etc.). Differences between the two forms are marked, with, for the less compact form, double the area seen of grey infrastructures and industrial or commercial buildings. The landscape seen from town centres thus appears far more closed-in.

Table 6. Mean area (ares) covered by buildings and grey infrastructure objects in the viewshed

\begin{tabular}{|l|c|c|}
\hline \multicolumn{1}{|c|}{ Buildings and grey infrastructure objects } & $\begin{array}{c}\text { High-density } \\
\text { built areas }\end{array}$ & $\begin{array}{c}\text { Low-density } \\
\text { built areas }\end{array}$ \\
\hline Low-rise homes and businesses & 2.5 & 2.6 \\
\hline High-rise homes and businesses & 2.3 & 3.0 \\
\hline Commercial, industrial, leisure and educational facilities & 1.7 & 4.6 \\
\hline Agricultural facilities (buildings, greenhouses) & 1.5 & 3.0 \\
\hline Grey infrastructures (footpaths, parking areas, roads, railways, etc. & 32.4 & 73.1 \\
\hline
\end{tabular}

Green objects offer large areas to be seen, except for shrubs/bushes. Fields cover 32000 ares in landscapes seen from the built areas in compact form and 51600 in less compact form. Then come trees, vineyards and water bodies. Smaller areas of meadows/grass are visible.

Table 7. Mean area (ares) covered by green and blue spaces in the viewshed 


\begin{tabular}{|l|c|c|}
\hline \multicolumn{1}{|c|}{ Green and water objects } & $\begin{array}{c}\text { High-density } \\
\text { built areas }\end{array}$ & $\begin{array}{c}\text { Low-density } \\
\text { built areas }\end{array}$ \\
\hline Trees / Woods / Forests & 4169 & 13394 \\
\hline Bushes / Shrubs & 3.3 & 8 \\
\hline Vineyards & 6238 & 7630 \\
\hline Meadows / Grass & 436 & 769 \\
\hline Fields & 32600 & 51616 \\
\hline Water bodies & 1809 & 3238 \\
\hline
\end{tabular}

5. Discussion

Considering land cover as a spatial arrangement of physical objects (Geoghegan et al., 1997) leads to a partial evaluation of the landscape since the means of perceiving it are omitted. Paterson \& Boyle (2002) resorted to the three-dimensional model view but ignoring the masking effects of tall objects, which overestimates the viewshed, especially when the foreground contains trees or houses. Lake et al. (1998) clearly showed the value of simulations restoring the actual view of landscapes as far as possible. In line with this, our contribution makes it possible to model the visible landscape by emphasizing the composition and weight of the objects of which it is composed.

\subsection{Quality of inputs and results}

Two main data sources were used as inputs for the viewshed computational tool: a digital elevation model and a land-use layer. Despite the care taken in constructing them, the resolution of the former and the random generation of the vegetation in the urbanized areas of the second must be discussed.

The information of the $5 \mathrm{~m}$ DEM resolution is of the same quality as in the original $50 \mathrm{~m}$ DEM resolution; no elevational precision is created to account for topographic forms on less than a $50 \mathrm{~m}$ scale. Even if the elevation of the main skeleton lines is maintained, the variation in elevation is smoothed and may conceal the sometimes rough character of the topography. Results for the viewshed may therefore be locally biased: in some places the viewshed could be partly overestimated. It is difficult to estimate the influence of bias introduced by such modelling on the quality of our results (Fisher, 1995). It is probably weaker when the topography is made up of lowlands and smooth slopes, as in the agglomerations of our study area, where the amplitude of view is mostly determined by the land use.

The land-use layer is formed from fine-scale vector information that can be used to identify objects of land use to be seen at $5 \mathrm{~m}$ resolution. However, the small green patches (grass, trees, shrubs and bushes) present in non-built and non-parking areas in the urban footprint were generated randomly in proportion to the areas identified visually on orthophotos, which is a critical point. The result is consistent with reality and the random distribution of objects should not markedly affect the statistics 
derived from it. In particular, the overabundance of trees in the urban landscapes of Côte-d'Or confirms that such vegetation is generally very much a feature of urbanized zones (Artmann et al., 2017a; Davies et al., 2015; European Environment Agency (EEA), 2011).

\subsection{Proportion of areas in view}

The proportion of areas actually seen compared with the potential viewshed is an interesting idea for discussion as it shows the level of confinement of urban spaces. At sea, it is possible to see as far as the curvature of the Earth allows. On land, it is rare to be able to see so far because of the interplay of relief and geographical objects spread across the ground surface. Only certain sites on open topographical high points provide a panoramic view. As a rule, agglomerations are in valley bottoms and, if it is added that the view is systematically broken at a short distance by the visual masks all round, it can be assumed that conditions are seldom suitable for clear views. Our results indicate as much since only $2.9 \%$ of the potentially visible space is actually visible from high-density built areas, as opposed to $4.6 \%$ for low-density built areas.

\subsection{Frequency and mean areas in view}

The frequency of objects seen is not necessarily correlated with the area they occupy within the viewshed. Low-rise residential buildings are often in view (65\% of viewsheds, tab. 4), but the area they occupy in the viewshed is small (4.3 ares on average, tab. 6). Because residential buildings are found everywhere in urban settings, they are often visible. But beyond the first house in sight, the view is masked and only rarely can other objects be seen behind them. As a result, the viewshed surface is low. As a rule, the area of the viewfield covered by man-made objects is low, except for items with zero elevation (roads, parking areas) that do not block the view and so can be seen in full. In other instances, items are infrequent in the viewshed but take up a lot of space. This arrangement occurs for vineyards, which are seldom visible from agglomerations ( $2 \%$ of viewsheds) but the area of which is high when they are in sight, averaging 130 ha. This apparent contradiction can be explained by the vineyards being located in a long strip on the côte bourguignonne. This is also true of trees and grass but because such objects are often visible, there seems nothing surprising about it.

Fields and meadows/grass do not produce the same effect. Because they have zero height, they should both allow vast views into the distance. This is only true for cropland though (mean area seen 769 ha versus 31 for meadows). Yet fields are visible much less often than meadows/grass (27 versus $74 \%$ of viewsheds). This is because of the setting in which they are found. Grass is found everywhere, unlike fields that are found only outside of agglomerations. Accordingly grass areas are often within view but their visual extent is quickly blocked by objects of some height (buildings, shrubs) that limit 
the area actually seen. This is not so for fields which are less often visible but can be seen from further away because of wide open views; the area seen therefore increases quickly.

\subsection{Relevance for urban and regional applications and management}

For Graça et al. (2018), much progress has been made in identifying, quantifying and evaluating multiple urban ecosystem services (UES). However, this knowledge is rarely taken into account in urban planning and management. Specifically, acknowledging how patterns of UES are related to the structure and composition of urban green areas could help stakeholders to target structural variables that increase UES provision. On the other hand, authorities are generally only interested in the urban green fraction for which they are responsible, regardless of agricultural land, private green spaces or informal green spaces, whereas all green spaces count in the light of ecosystem services provided by green infrastructure.

Landscape properties can be viewed as the basis for analysis before an evaluation of the potential and services provided by environmental amenities. In the debate on urban sprawl, an issue that is not yet sufficiently resolved is that people who enjoy the aesthetic quality of the landscape seem to contribute to sprawl because they wish to live closer to nature. Compact urban forms have a priori less green space than sprawling cities (Artmann et al., 2017b) and the supply of ecosystem services is lower than demand for them (Larondelle and Lauf, 2016). Too few green spaces could compromise the adequate supply of urban ecosystem services (Anguluri and Narayanan, 2017; Haaland and Konijnendijk van den Bosch, 2015; Neuman, 2005). There are no clear views about how to approach compact and green cities. In particular, there is a shortage of concepts integrating both research and urban planning practice with which to address compact and green cities. Our results show that indeed, greenery occupies a small area in compact building areas. Nevertheless, trees, woods, forest, bushes, shrubs, meadows and grassy plots are common in the urban landscapes, thus offering a living environment desired by residents. These findings have implications for understanding the distribution of aesthetic services provided by green spaces in urban landscapes, as well as for managing development to achieve the planners' housing density objectives.

\section{Conclusion}

The question of the search for a "green" living environment has been addressed using a quantitative method for identifying and measuring landscape features. To do this, a GIS based-method, combining a DEM and a land-use layer, has been used to construct landscape indicators and produce statistics describing the visible landscape. The main results of this geographic approach are the following. In the study area (Côte-d'Or, France), counterintuitively urban forms provide a lot of greenery in their landscape. In the compact built areas of town centres, the landscape is dominated by trees, low-rise 
residential buildings and grassy areas. Grey infrastructures and bushes are also very much present. They provide a varied landscape in which collective facilities and high-rise residential buildings are discreet. The landscape is also very closed-in with the result that the total of spaces seen there narrowly exceeds $7600 \mathrm{~km}^{2}$. In the less compact built areas, the hierarchy of objects within sight is similar but with much lower frequencies. For example, trees that are found in $94 \%$ of viewsheds in compact built areas are found in only $55 \%$ of viewsheds in less compact areas. However, as the scenery is less closed-in, the viewshed is wider $\left(20000 \mathrm{~km}^{2}\right)$.

Greenery is an important factor for the health of inhabitants and quality of urban life. Whether planned or not, it is important for vegetation to be present in landscapes whatever the morphology of the urban fabric.

\section{Acknowledgements}

The research reported in this paper was funded by the European Union under the seventh framework program. It is a component of the RURAGRI ERA-NET TRUSTEE project (Towards RUral Synergies and Trade-offs between Economic development and Ecosystem services) carried out under Grant Agreement no. 235175 (ANR-13-RURA-0001-01) (www.trustee-project.eu).

\section{References}

Ahern, J., 2007. Green infrastructure for cities: the spatial dimension. Cities Futur. Integr. Sustain. Water Landsc. Manag. 267-283.

Ai, T., Li, J., 2010. A DEM generalization by minor valley branch detection and grid filling. ISPRS J. Photogramm. Remote Sens. 65, 198-207. doi:10.1016/j.isprsjprs.2009.11.001

Alavipanah, S., Haase, D., Lakes, T., Qureshi, S., 2017. Integrating the third dimension into the concept of urban ecosystem services: A review. Ecol. Indic. doi:10.1016/j.ecolind.2016.08.010

Alberti, M., Marzluff, J.M., 2004. Ecological resilience in urban ecosystems: linking urban patterns to human and ecological functions. Urban Ecosyst. 7, 241-265.

doi:10.1023/B:UECO.0000044038.90173.c6

Andersson, E., Colding, J., 2014. Understanding how built urban form influences biodiversity. Urban For. Urban Green. 13, 221-226. doi:10.1016/j.ufug.2013.11.002

Anguluri, R., Narayanan, P., 2017. Role of green space in urban planning: Outlook towards smart cities. Urban For. Urban Green. 25, 58-65. doi:10.1016/j.ufug.2017.04.007

Anselin, L., 1995. Local Indicators of Spatial Association - LISA. Geogr. Anal. 27, 93-115. doi:10.1111/j.1538-4632.1995.tb00338.x

Artmann, M., Bastian, O., Grunewald, K., 2017a. Using the Concepts of Green Infrastructure and Ecosystem Services to Specify Leitbilder for Compact and Green Cities-The Example of the Landscape Plan of Dresden (Germany). doi:10.3390/su9020198

Artmann, M., Kohler, M., Meinel, G., Gan, J., loja, I.-C., 2017b. How smart growth and green infrastructure can mutually support each other - A conceptual framework for compact and 
green cities. doi:10.1016/j.ecolind.2017.07.001

Bolund, P., Hunhammar, S., 1999. Ecosystem services in urban areas. Ecol. Econ. 29, 293-301. doi:10.1016/S0921-8009(99)00013-0

Caruso, G., Hilal, M., Thomas, I., 2017. Measuring urban forms from inter-building distances: Combining MST graphs with a Local Index of Spatial Association. Landsc. Urban Plan. 163, 8089. doi:10.1016/j.landurbplan.2017.03.003

Chan, K.M.A., Satterfield, T., Goldstein, J., 2012. Rethinking ecosystem services to better address and navigate cultural values. Ecol. Econ. 74, 8-18. doi:10.1016/j.ecolecon.2011.11.011

Chang, J., Qu, Z., Xu, R., Pan, K., Xu, B., Min, Y., Ren, Y., Yang, G., Ge, Y., 2017. Assessing the ecosystem services provided by urban green spaces along urban center-edge gradients. Sci. Rep. 7, 11226. doi:10.1038/s41598-017-11559-5

Clay, G.R., Daniel, T.C., 2000. Scenic landscape assessment: The effects of land management jurisdiction on public perception of scenic beauty. Landsc. Urban Plan. 49, 1-13. doi:10.1016/S0169-2046(00)00055-4

Conedera, M., Del Biaggio, A., Seeland, K., Moretti, M., Home, R., 2015. Residents' preferences and use of urban and peri-urban green spaces in a Swiss mountainous region of the Southern Alps. Urban For. Urban Green. 14, 139-147. doi:10.1016/j.ufug.2015.01.003

Davies, C., Hansen, R., Rall, E., Pauleit, S., Lafortezza, R., De Bellis, Y., Santos, A., Tosics, I., 2015. Green infrastructure planning and implementation.

Davodeau, H., 2005. La sensibilité paysagère à l'épreuve de la gestion territoriale. Cah. Geogr. Que. 49, 177. doi:10.7202/012299ar

De Floriani, L., Magillo, P., 1999. Intervisibility on Terrains, in: Longley, P., Goodchild, M., Maguire, D., Rhind, D. (Eds.), Geographic Information Systems: Principles, Techniques, Applications and Management. Wiley, New-York.

De Floriani, L., Marzano, P., Puppo, E., 1994. Line-of-sight communication on terrain models. Int. J. Geogr. Inf. Syst. 8, 329-342. doi:10.1080/02693799408902004

Ellis, C.D., Lee, S.-W., Kweon, B.-S., 2006. Retail land use, neighborhood satisfaction and the urban forest: an investigation into the moderating and mediating effects of trees and shrubs. Landsc. Urban Plan. 74, 70-78. doi:10.1016/j.landurbplan.2004.10.004

Ervin, D.E., Brown, D., Chang, H., Dujon, V., Granek, E.F., 2012. Growing Cities Depend on Ecosystem Services. Grow. Cities Depend Ecosyst. Serv. Solut. 2, 74-86.

European Environment Agency (EEA), 2011. Green infrastructure and territorial cohesion. The concept of green infrastructure and its integration into policies using monitoring systems. Luxembourg. doi:10.2800/88266

Figueroa-Alfaro, R.W., Tang, Z., 2017. Evaluating the aesthetic value of cultural ecosystem services by mapping geo-tagged photographs from social media data on Panoramio and Flickr. J. Environ. Plan. Manag. 60, 266-281. doi:10.1080/09640568.2016.1151772

Fisher, P.F., 1995. An exploration of probable viewsheds in landscape planning. Environ. Plan. B Plan. Des. 22, 527-546. doi:10.1068/b220527

Geoghegan, J., Wainger, L.A., Bockstael, N.E., 1997. Spatial landscape indices in a hedonic 
framework: an ecological economics analysis using GIS. Ecol. Econ. 23, 251-264. doi:10.1016/S0921-8009(97)00583-1

Gobster, P.H., Nassauer, J.I., Daniel, T.C., Fry, G., 2007. The shared landscape: What does aesthetics have to do with ecology? Landsc. Ecol. 22, 959-972. doi:10.1007/s10980-007-9110-x

Gómez-Baggethun, E., Barton, D.N., 2013. Classifying and valuing ecosystem services for urban planning. Ecol. Econ. 86, 235-245. doi:10.1016/j.ecolecon.2012.08.019

Graça, M., Alves, P., Gonçalves, J., Nowak, D.J., Hoehn, R., Farinha-Marques, P., Cunha, M., 2018. Assessing how green space types affect ecosystem services delivery in Porto, Portugal. Landsc. Urban Plan. 170, 195-208. doi:10.1016/j.landurbplan.2017.10.007

Gruber, K.J., Shelton, G.G., 1987. Assessment of neighborhood satisfaction by residents of three housing types. Soc. Indic. Res. 19, 303-315. doi:10.1007/BF00300363

Haaland, C., Konijnendijk van den Bosch, C., 2015. Challenges and strategies for urban green-space planning in cities undergoing densification: A review. Urban For. Urban Green. 14, 760-771. doi:10.1016/j.ufug.2015.07.009

Hands, D.E., Brown, R.D., 2002. Enhancing visual preference of ecological rehabilitation sites. Landsc. Urban Plan. 58, 57-70. doi:10.1016/S0169-2046(01)00240-7

Hilal, M., Legras, S., Cavailhès, J., 2017. Peri-Urbanisation: Between Residential Preferences and Job Opportunities. Raumforsch. und Raumordnung - Spat. Res. Plan. 1-15. doi:10.1007/S13147016-0474-8

Hilal, M., Martin, E., Piguet, V., 2016. Prediction of the purchase cost of agricultural land: The example of Côte-d'Or, France. Land use policy 52. doi:10.1016/j.landusepol.2016.01.005

Hur, M., Morrow-Jones, H., 2008. Factors That Influence Residents' Satisfaction With Neighborhoods. Environ. Behav. 40, 619-635. doi:10.1177/0013916507307483

Hur, M., Nasar, J.L., Chun, B., 2010. Neighborhood satisfaction, physical and perceived naturalness and openness. J. Environ. Psychol. 30, 52-59. doi:10.1016/j.jenvp.2009.05.005

Irwin, E.G., Bockstael, N.E., 2001. The Problem of Identifying Land Use Spillovers: Measuring the Effects of Open Space on Residential Property Values. Amer. J. Agr. Econ 83, 698-704.

Joly, D., Bois, B., Zaksek, K., 2012. Rank-Ordering of Topographic Variables Correlated with Temperature. Atmos. Clim. Sci. 2, 139-147. doi:10.4236/acs.2012.22015

Joly, D., Brossard, T., Cavailhès, J., Hilal, M., Tourneux, F.-P., Tritz, C., Wavresky, P., 2009. A Quantitative approach to the visual evaluation of landscape. Ann. Assoc. Am. Geogr. 99, 292308. doi:10.1080/00045600802708473

Kearney, A.R., 2006. Residential Development Patterns and Neighborhood Satisfaction: Impacts of Density and Nearby Nature. Environ. Behav. 38, 112-139. doi:10.1177/0013916505277607

Klein, L.R., 2013. Quantifying relationships between ecology and aesthetics in agriculture landscapes. Washington State University.

Klouček, T., Lagner, O., Šímová, P., 2015. How does data accuracy influence the reliability of digital viewshed models? A case study with wind turbines. Appl. Geogr. 64, 46-54. doi:10.1016/j.apgeog.2015.09.005 
Lake, I.R., Lovett, A.A., Bateman, I.J., Langford, I.H., 1998. Modelling environmental influences on property prices in an urban environment. Comput. Environ. Urban Syst. 22, 121-136. doi:10.1016/S0198-9715(98)00012-X

Lamb, R.J., Purcell, A.T., 1990. Perception of naturalness in landscape and its relationship to vegetation structure. Landsc. Urban Plan. 19, 333-352. doi:10.1016/0169-2046(90)90041-Y

Larondelle, N., Lauf, S., 2016. Balancing demand and supply of multiple urban ecosystem services on different spatial scales. Ecosyst. Serv. 22, 18-31. doi:10.1016/j.ecoser.2016.09.008

Le Jeannic, T., 1997. Trente ans de périurbanisation : extension et dilution des villes. Econ. Stat. 307, 21-41. doi:10.3406/estat.1997.2578

Lee, S.-W., Ellis, C.D., Kweon, B.-S., Hong, S.-K., 2008. Relationship between landscape structure and neighborhood satisfaction in urbanized areas. Landsc. Urban Plan. 85, 60-70. doi:10.1016/j.landurbplan.2007.09.013

Li, X., Zhang, C., Li, W., Ricard, R., Meng, Q., Zhang, W., 2015. Assessing street-level urban greenery using Google Street View and a modified green view index. Urban For. Urban Green. 14, 675685. doi:10.1016/j.ufug.2015.06.006

Loures, L., Loures, A., Nunes, J., Panagopoulos, T., 2015. Landscape valuation of environmental amenities throughout the application of direct and indirect methods. Sustain. 7, 794-810. doi:10.3390/su7010794

Matsuoka, R.H., Kaplan, R., 2008. People needs in the urban landscape: Analysis of Landscape And Urban Planning contributions. Landsc. Urban Plan. 84, 7-19. doi:10.1016/j.landurbplan.2007.09.009

Neuman, M., 2005. The Compact City Fallacy. J. Plan. Educ. Res. 25, 11-26. doi:10.1177/0739456X04270466

Nijhuis, S., van Lammeren, R., van der Hodven, F., 2011. Exploring the Visual Landscape. doi:10.7480/rius.2.205

Palmer, E., 2000. Reliability of Rating Visible Landscape Qualities. Landsc. J. 19, 166-178. doi:10.3368/lj.19.1-2.166

Paterson, R.W., Boyle, K.J., 2002. Out of Sight, Out of Mind? Using GIS to Incorporate Visibility in Hedonic Property Value Models. Land Econ. 78, 417-425. doi:10.2307/3146899

PostGIS, 2018. Manuel PostGIS 2.4.0.

Sahraoui, Y., Vuidel, G., Foltête, J.-C., Joly, D., 2016a. PixScape - un outil logiciel intégré pour I'analyse du paysage visible. Cybergeo. doi:10.4000/cybergeo.27862

Sahraoui, Y., Vuidel, G., Foltête, J.-C., Joly, D., 2016b. PixScape.

Shechter, M., Enis, R., Reiser, B., Tzamir, Y., 1981. Evaluation of landscape resources for recreation planning. Reg. Stud. 15, 373-390. doi:10.1080/09595238100185361

Smith, G., Beare, M., Boyd, M., Downs, T., Gregory, M., Morton, D., Brown, N., Thomson, A., 2007. UK Land Cover Map Production Through the Generalisation of OS MasterMap ${ }^{\circledR}$. Cartogr. J. 44, 276-283. doi:10.1179/000870407X241827

Tannier, C., Bourgeois, M., Houot, H., Foltête, J.C., 2016. Impact of urban developments on the 
functional connectivity of forested habitats: A joint contribution of advanced urban models and landscape graphs. Land use policy 52, 76-91. doi:10.1016/j.landusepol.2015.12.002

Thiemann, F., Sester, M., Bobrich, J., 2010. Automatic Derivation of Land-Use From Topographic Data. Int. Soc. Photogramm. Remote Sens. 558-563.

Tveit, M., Ode, Å., Fry, G., 2006. Key concepts in a framework for analysing visual landscape character. Landsc. Res. 31, 229-255. doi:10.1080/01426390600783269

Tyrväinen, L., Silvennoinen, H., Kolehmainen, O., 2003. Ecological and aesthetic values in urban forest management. Urban For. Urban Green. 1, 135-149. doi:10.1078/1618-8667-00014

Tzoulas, K., Korpela, K., Venn, S., Yli-Pelkonen, V., Kaźmierczak, A., Niemela, J., James, P., 2007. Promoting ecosystem and human health in urban areas using Green Infrastructure: A literature review. Landsc. Urban Plan. 81, 167-178. doi:10.1016/j.landurbplan.2007.02.001

Velarde, M.D., Fry, G., Tveit, M., 2007. Health effects of viewing landscapes - Landscape types in environmental psychology. Urban For. Urban Green. 6, 199-212.

doi:10.1016/j.ufug.2007.07.001

Wen, H., Zhang, Y., Zhang, L., 2015. Assessing amenity effects of urban landscapes on housing price in Hangzhou, China. Urban For. Urban Green. 14, 1017-1026. doi:10.1016/j.ufug.2015.09.013

Williams, K.J.H., Cary, J., 2002. Landscape preferences, ecological quality, and biodiversity protection. Environ. Behav. 34, 257-274. doi:10.1177/0013916502034002006

Wolch, J.R., Byrne, J., Newell, J.P., 2014. Urban green space, public health, and environmental justice: The challenge of making cities "just green enough." Landsc. Urban Plan. 125, 234-244. doi:10.1016/j.landurbplan.2014.01.017

Wu, B., Yu, B., Wu, Q., Chen, Z., Yao, S., Huang, Y., Wu, J., 2017. An Extended Minimum Spanning Tree method for characterizing local urban patterns. Int. J. Geogr. Inf. Sci. 0, 1-26. doi:10.1080/13658816.2017.1384830

Wyatt, P., 2004. Constructing a land-use data set from public domain information in England. Plan. Pract. Res. 19, 147-171. doi:10.1080/0269745042000284395

Yu, B., Liu, H., Wu, J., Hu, Y., Zhang, L., 2010. Automated derivation of urban building density information using airborne LiDAR data and object-based method. Landsc. Urban Plan. 98, 210219. doi:10.1016/j.landurbplan.2010.08.004

Zakšek, K., Podobnikar, T., 2005. an Effective Dem Generalization With Basic Gis Operations. 8th ICA Work. Gen. Mult. Represent.

Zhou, Q., Chen, Y., 2011. Generalization of DEM for terrain analysis using a compound method. ISPRS J. Photogramm. Remote Sens. 66, 38-45. doi:10.1016/j.isprsjprs.2010.08.005 
Annex 1

\begin{tabular}{|c|c|c|}
\hline CLC & CLC description & LUL (land-use layer) \\
\hline 122 & Road and rail networks and associated land & Artificialized surfaces \\
\hline 123 & Port areas & Artificialized surfaces \\
\hline 131 & Mineral extraction sites & Artificialized surfaces \\
\hline 133 & Construction sites & Artificialized surfaces \\
\hline 322 & Moors and heathland & Bushes \\
\hline 211 & Non-irrigated arable land & Fields \\
\hline 243 & $\begin{array}{l}\text { Land principally occupied by agriculture, with } \\
\text { significant areas of natural vegetation }\end{array}$ & Fields $90 \%$; trees $10 \%$ \\
\hline 511 & Water courses & Water bodies \\
\hline 512 & Water bodies & Water bodies \\
\hline 311 & Broad-leaved forest & Forests \\
\hline 312 & Coniferous forest & Forests \\
\hline 313 & Mixed forest & Forests \\
\hline 324 & Transitional woodland-shrub & Forests \\
\hline 124 & Airports & Meadows \\
\hline 231 & Pastures & Meadows \\
\hline 321 & Natural grasslands & Meadows \\
\hline 411 & Inland marshes & Meadows \\
\hline 242 & Complex cultivation patterns & Meadows $90 \%$; trees $10 \%$ \\
\hline 111 & Continuous urban fabric & $\begin{array}{l}\text { Meadows or grass } 50 \% \text {; trees } 25 \% \text {; bushes } \\
25 \%\end{array}$ \\
\hline 112 & Discontinuous urban fabric & $\begin{array}{l}\text { Meadows or grass } 50 \% \text {; trees } 25 \% \text {; bushes } \\
25 \%\end{array}$ \\
\hline 121 & Industrial or commercial units & $\begin{array}{l}\text { Meadows or grass } 50 \% \text {; trees } 25 \% \text {; bushes } \\
25 \%\end{array}$ \\
\hline 141 & Green urban areas & $\begin{array}{l}\text { Meadows or grassy spots } 50 \% \text {; trees } 25 \% \text {; } \\
\text { bushes } 25 \%\end{array}$ \\
\hline 142 & Sport and leisure facilities & $\begin{array}{l}\text { Meadows or grassy spots } 50 \% \text {; trees } 25 \% \text {; } \\
\text { bushes } 25 \%\end{array}$ \\
\hline 222 & Fruit trees and berry plantations & Meadows or grass $30 \%$; bushes $25 \%$ \\
\hline 221 & Vineyards & Vineyards \\
\hline
\end{tabular}

Some items of the land-use layer are composed of several simple objects attributed by disaggregation. The proportions used in the disaggregation of heterogeneous or complex items of the land-use layer are determined by careful observation of orthorectified aerial photographs. 